\title{
Az egészség ökoszociális elmélete
}

\author{
Ecosocial theory of health
}

\author{
Szerző: Csizmadia Péter $\bowtie$ \\ Emberi Erőforrások Minisztériuma
}

Beküldve: 2017. 09. 12.

doi: $10.24365 /$ ef.v58i3.181

\begin{abstract}
Összefoglaló: A cikk célja az ökoszociális elmélet ismertetése, amelyet Nancy Krieger dolgozott ki 1994-ben. Egy átfogó elméletről van szó, amelynek célja az ok-okozati kapcsolatok bemutatása és magyarázata a betegségek előfordulása és az egészség terén. Az elmélet részét képezik biológiai és pszichoszociális elemek. Ezen túlmenően a társadalmi tényezők egészségre gyakorolt hatást is vizsgálja. Az elmélet középpontjában a beépülés, a beépülés útvonalai, az egészségkárosító tényezőknek való kitettség kölcsönhatásai, az érzékenység, a hajlam és az ellenálló képesség, a felelősség és képesség áll. Az elmélet valószínűsíti, hogy az egészséget különböző társadalmi és térbeli szintek határozzák meg, és ezek vizsgálatakor történelmi, politikai-gazdasági, idő és térbeli tényezőket kell figyelembe venni.
\end{abstract}

Kulcsszavak: ökológia; egészségegyenlőtlenségek

Summary: This article aims to introduce the Ecosocial Theory. The theory which was first proposed in 1994 by Nancy Krieger, is a broad and complex theory with the purpose of describing and explaining causal relationships in disease distribution and health. While it incorporates biological and psychosocial influences on health, the theory is also suited to analyze the relationships between social factors and health. The core constructs of Ecosocial Theory are: Embodiment; Pathways to Embodiment; the cumulative interplay between exposure, resistance, and susceptibility; and agency and accountability. The theory assumes that health is determined at multiple levels and that analyses must incorporate historical, political economic, temporal, and spatial analyses.

Keywords: ecology; health inequalities

\section{BEVEZETÉS}

Az egészség mibenlétére vonatkozóan az idők folyamán többféle elképzelés, modell is született. A kilencvenes évek egyik alapvető egészségelmélete a súlypontot arra a kétségbevonhatatlan tényre helyezte, hogy az egészséges életmód, a megfelelő egészségmagatartás elengedhetetlen feltétele egészségünknek. Az egészség - a modell szerint - az egészséges életmód akadályainak felszámolása (egészséges táplálkozás, testedzés, dohányzás, alkoholfogyasztástól való tartózkodás stb.) révén érhető el. Az elmélet kevés figyelmet fordított az egészség társadalmi meghatározóira, annak társadalmi beágyazottságára. Az életmódot az egyéni döntések sorozatának tekinti, gyakorlatilag szabadon választott rizikófaktorokról beszél, amelyek vagy ártalmasak, vagy kedvezőek az egészségre.

A korszak másik, a nyugati orvoslás tudományos megközelítését alkalmazó, úgynevezett biomedikális modell az egészséget az emberi szervezet összetett biokémiai entitásaként értelmezi. A 
testi szinten jelentkező betegségek hátterében többlépéses, de jól követhető ok-okozati összefüggés-láncolat áll, amelyet az elemi alkotórészek szintjén lehet a legjobban kezelni. A modern orvoslás figyelmének középpontjában tehát a molekuláris és elektrokémiai zavarok állnak; az embereket érő egyéb hatásokra sokkal kevesebb figyelem jut. Ebből következően, az orvosi tudás objektíven alkalmazható mindenféle 'emberi molekulahalmazra', függetlenül az adott személytől vagy annak a környezetével való kapcsolatától. Az egészség kvantifikálható, mennyiségileg kifejezhető oly módon, hogy az azt jellemző mutatók értékeit populációkra, csoportokra vagy egyénekre megadott normákhoz (normálértékekhez) viszonyítjuk.

Az itt csak röviden, vázlatosan bemutatott modellek mellett az ökológiai személetmód elterjedésével az 1990-évek közepén új kezdeményezések jelentek meg a tudományos életben, amelyek hatására az egészségtudományokban is megkezdődött az integratív, többszintű és dinamikus koncepciók kidolgozása. Az egészséggel kapcsolatos új megközelítésmódok egyike a Nancy Krieger nevéhez fúződő ökoszociális elmélet. ${ }^{1(p 21-23), 2}$

\section{AZ ELMÉLET ELŐZMÉNYEI}

A teória előzményei között megemlíthetjük a szociálepidemiológiának nevezett, illetve az egészség társadalmi meghatározóinak jelentőségét hangsúlyozó irányzatokat, amelyek fókuszában a betegségek megoszlásának társadalmi különbségei álltak, a hatalom, a politika, a gazdaság és a jogok vonatkozásában. Úgy érvelnek, hogy társadalmi tényezők (upstream, distal) hozzák létre azokat a mintázatokat, amelyek a népesség és az egyén közti viszonyokat és az egészséget meghatározzák.

Krieger elméletének előzményei között az elsősorban a pszichológiában használt fejlődésökológiai elmélet is megemlítendő, melyet Bronfenbrenner dolgozott ki. ${ }^{3,4}$ Ő azt hangsúlyozta, hogy az emberi fejlődés csak a teljes társas-társadalmi (ökológiai) környezet matrjoska babákhoz hasonlóan egymásba ágyazott struktúráinak figyelembevételével érthető meg.

Nézetei szerint a társadalmi hatásoknak különböző szintjei vannak, amelyek a mindennapi rutinoktól az intézményeken keresztül a kultúra által közvetített nézetekig terjednek. Ezek a szintek egymásra épülve, külön-külön rendszereket alkotnak, amelyeket mikro-, mezo- és makrorendszernek nevezett el.

\section{AZ ÖKOSZOCIÁLIS GONDOLKODÁS ALAPELVEI}

Mielőtt rátérünk Krieger elméletének részletesebb ismertetésére, célszerűnek látszik az ökológia kifejezésnél elidőzni. Az ökológia szót Ernst Haeckel, német zoológus és filozófus alkotta a görög oikosz (ház, lakás) és logosz (szó, beszéd, tan, tudomány) szavakból. Nincs még egy tudomány, aminek ilyen sok és ennyire különböző definíciója látott volna napvilágot. Maga Haeckel is több meghatározást adott; ezekben megjelenik az ökológiának a fiziológiától való elhatárolása, az élőlények és az azokat körülvevő környezet viszonyával foglalkozó tudomány, valamint a Linné-féle „természet ökonómiája”, összekapcsolva a fajok közötti komplex összefüggésekkel, amelyeket Darwin a létért való küzdelem feltételeinek nevezett. Később az állatökológusok inkább az élőlények elterjedési mintázatait, a növényökológusok a társulások szerkezetét és mechanizmusait hangsúlyozták definícióikban. 
Krieger szerint az ökológia kifejezés használata esetében az alábbi feltételek elfogadása szükséges:

- Az élőlények és a környezet kölcsönösen egymásra utaltak. Ez maga után vonja az idő és a tér kapcsolódását szintenként vizsgáló elemzéseket, továbbá hangsúlyozza az egyidejű folyamatok tér- és időbeliségét, amelyek emellett földrajzi és történeti vetülettel is rendelkeznek.

- Az individuális organizmusok (az embereket is beleértve) szükségszerūen egy populáció részeit képezik. Mindkettő meghatározott a környezetük által, illetve visszahatnak, formálják azt.

- Az ok-okozati mechanizmusok feltárása szükségszerü.

Miért fontosak ezek a látszólag csak az ökológia tudományán belül releváns megállapítások az epidemiológia számára? Nancy Krieger válasza az, hogy az ökológiai szemléletmód a más területen tevékenykedők számára is hasznos nézőpontot biztosít. Idézzük az általa alapvetőnek tartott kérdést: „Ki és mi okozza az egészségegyenlőtlenségek jelenlegi és változó mintázatait?" Krieger szerint az egészségtudományokban is nagyobb figyelmet kell szentelni a társadalmi tényezőknek és az ökológiai háttérnek.
Véleménye szerint az életút és a generációs megközelítés, a szintek elkülönült analízise, a társadalmi egyenlőtlenségek közötti kölcsönhatások, beleértve a nemzetiségi, a rasszbeli, az osztály- és a genderalapú egyenlőtlenségeket, alapvető fontosságúak. (Krieger elméletét illusztrálja az 1. ábra. A modellről részletesebben olvashatnak az alább hivatkozott tanulmányban. ${ }^{5}$ )

Az ökoszociális elmélet első alapelve a beépülés (embodiment). Lényege, hogy a megélt tapasztalatok biológiai folyamatok révén beépülnek és rögzülnek az emberi szervezetben. A beépülés alapelve a társadalmilag determinált és korszakonként változó egészségegyenlőtlenségeket nem az egyéni belső jellemzők által meghatározottnak, hanem külső eredetűnek tekinti, még akkor is, ha az egyéni tulajdonságok és a magatartás nem elhanyagolható tényezők. Tehát az okozati összefüggést mutató nyíl a társadalmi feltételektől mutat az egyén egészségi állapota felé. A fogalomból következik, hogy az egészség pontos megértéséhez a háttér dinamikus analízisére van szükség. Krieger hangsúlyozza, hogy a környezeti hatások beépülése a szervezetbe nem a génállomány megváltozásával jelenik meg, hanem a meglévő gének kifejeződése, azaz a szervezet tulajdonságaira gyakorolt hatásuk változik.

1. ábra: Az ökoszociális modell ábrázolása kiegészitve a hálózatkutatás megközelítésével

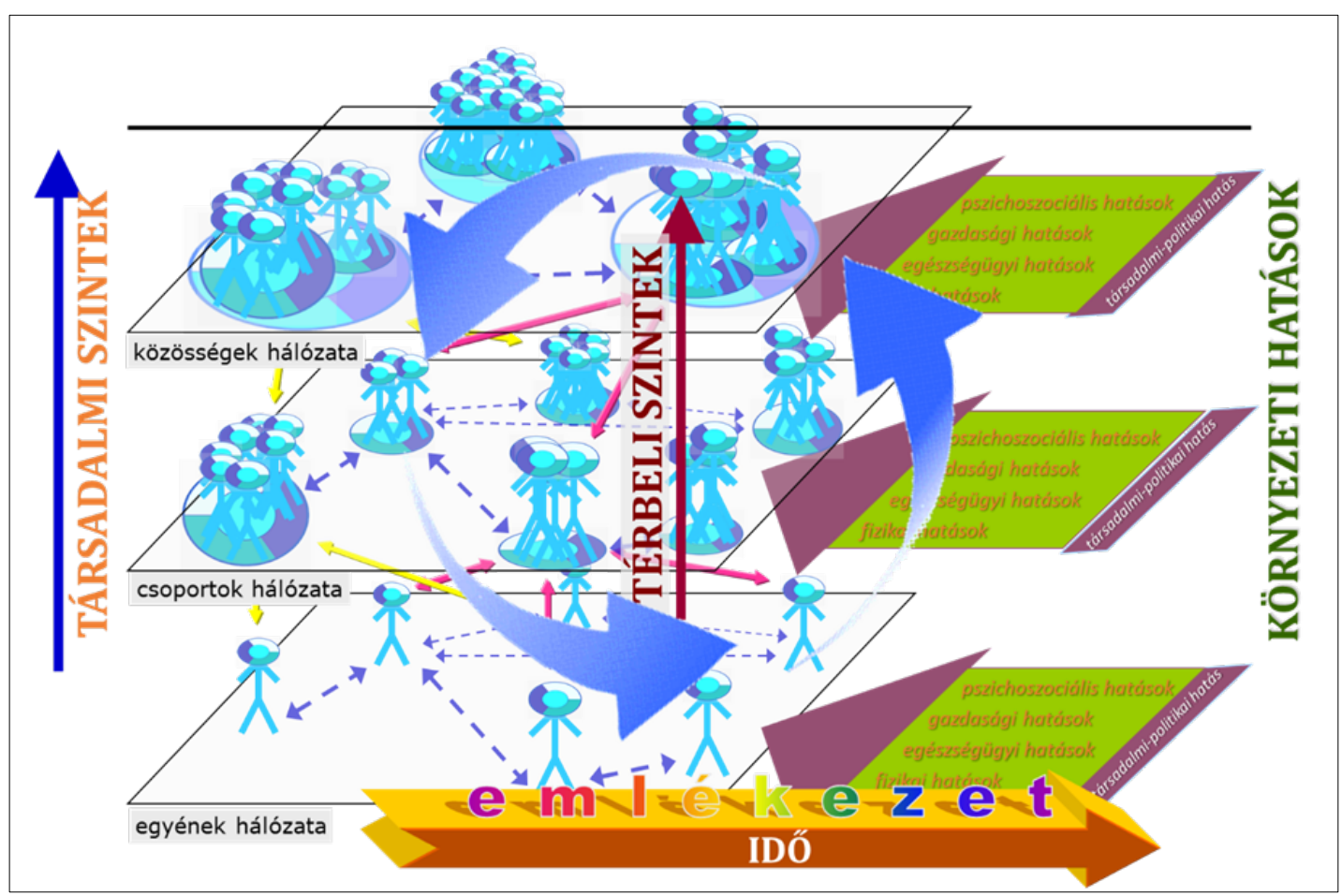

Forrás: Vitrai József ábrája, a szerző engedélyével. 
A következő jellemzője a beépülésnek, hogy a populációs csoportok között az egészségi állapotban megfigyelt különbségek a csoporton belüli kapcsolatokkal, és nem a biológiai okokkal vannak okozati összefüggésben inkább, még akkor is, ha a biológiai különbségek megjelennek az egyénekben.

Krieger a beépülés kapcsán többször hangsúlyozza az emberi közösségek történetiségét. Kiemeli, hogy az etnikai kisebbségek ellen társadalmilag-történelmileg meghatározott módon kialakuló előítéletek kedvezőtlenül befolyásolhatják ezeknek a csoportoknak az egészségi állapotát. Az etnikai csoportok körében a társadalmi változások hatására kialakuló egészségteherre az egyesült államokbeli epidemiológia egy ismert példája a 2-es típusú cukorbetegség megjelenése a pima indiánok között. ${ }^{1(2525-257)} \mathrm{Az}$ őslakosok között a cukorbetegség lényegében az 1940-es évekig ismeretlen volt. Az életfeltételeikben ez után bekövetkező radikális változások hatására a pima törzs tagjai között az elhízottak és cukorbetegségben szenvedők aránya kiemelkedően magassá vált.

A beépülés konstrukció használatával az ökoszociális elmélet nemcsak merít az ökológiai és biológiai elméletekből, de épít rá, sőt, kiterjeszti a szociológiai és antropológiai tudományosságot. Ezekben a tudományokban a beépülés elsősorban a kultuszok és hiedelmek megjelenő testi reprezentációjára vonatkozik.

Az ökoszociális elmélet második alapelve feltételezi, hogy a beépülés számos különböző összetett útvonalon zajlik le. Ezek az útvonalak változatosak, egyidejűek és egymással kölcsönhatásban állók, illetve különböző, az elmélet harmadik alapelvében részletezett tényezők által befolyásolt.

A harmadik alapelv tehát az egészségkárosító tényezőknek való kitettség kölcsönhatásaira, az érzékenységre, a hajlamra és az ellenálló-képességre összpontosít a különböző szinteken az életút és a különböző generációk élettörténete során. Ezek a beépülést befolyásoló tényezők a következők:

- gazdasági és társadalmi depriváció,

- mérgező anyagok, kórokozók és veszélyes életkörülmények,

- diszkrimináció és a társadalmi eredetű traumák egyéb formái (mentális, fizikai, szexuális, közvetlenül vagy közvetetten megtapasztalt a szóbeli fenyegetésektôl az erőszakos cselekedetig),
- $\quad$ az egészségkárosító árucikkek célzott marketingje (gyorséttermek kínálata, pszichoaktív szerek, mint a dohány- és alkoholtermékek, egyéb legális vagy illegális drogok),

- nem megfelelő egészségügyi ellátás,

- az ökológiai rendszer múködési hibái, beleértve a honos népesség szisztematikus elidegenedését az általuk használt és múvelt területektôl és a tradicionális gazdasági tevékenységüktől.

Az ökoszociális gondolkodás negyedik alapelve két fogalmat definiál: a felelősséget és aktivitásra való képességet (responsibility, agency). Mindkettő az egészségegyenlőtlenségekre vonatkozik, illetve azokra a módozatokra, ahogy azt monitorozzák, elemzik és kezelik. Mindkét kifejezés a politikai és gazdasági rendszer által kifejtett hatásra hívja fel a figyelmet, ahogyan ezek befolyásolják a népességen belül a betegségek előfordulását és az egészségegyenlőtlenségek kialakulását, fennmaradását. Ez az ökoszociális elem közvetlenül a hatalom kérdésére irányítja a figyelmet. Az intézmények és az egyének felelősségét vizsgálja abban a tekintetben, hogy aktívak, vagy inkább ellenkezőleg, elkerülik az aktivitást. A felelősség minden szinten való elismerése nem azt jelenti, hogy az minden szinten egyenlően oszlik meg. Sőt, inkább azt, hogy a makroszintű jelenségek nagyobb hatással, kényszerítő erővel bírnak a mezo- és mikroszintű jelenségek előmozdítására.

\section{ÖSSZEGZÉS}

A bemutatott ökoszociális egészségmodell az emberre ható jelenségek egymással minden szinten való egybefonódását hangsúlyozza. Kiemeli, hogy az egészséget meghatározó egyéni tényezőket - leszámítva az öröklött tulajdonságokat - jórészt a környezeti tényezők befolyásolják, és ezek között is a társadalmi-gazdasági-politikai körülmények azok, amelyek mint az „okok okai” valamennyi tényezőre hatással vannak. Kiemeli, hogy az egyének önkárosító magatartását is döntően meghatározza a külső

környezet. Emiatt a kockázati egészségmagatartás visszaszorítása is csakis a társadalmi-gazdasági-politikai környezet megfelelő változtatása révén lehet sikeres. 


\section{HIVATKOZÁSOK}

${ }^{1}$ Krieger N. Epidemiology and the People's Health: Theory and Context. Oxford University Press; 2011.

${ }^{2}$ Krieger N. Epidemiology and the web of causation: has anyone seen the spider? Soc Sci Med. 1994;39(7):887-903.

${ }^{3}$ N. Kollár K, Szabó É. Pszichológia pedagógusoknak. Kiadás városa: Kiadó neve; 2004. 21-3.

${ }^{4}$ Bronfenbrenner U. The Ecology of Human Development: Experiments by Nature and Design. Cambridge, MA: Harvard University Press; 1979.

${ }^{5}$ Vitrai J, Kimmel Z. Mennyire változtatható jogszabályokkal az egészségmagatartás? Mitől függ és hogyan változtatható az egészségmagatartás? I. rész. Egészségtudomány. 2015;3:57-70. http://egeszsegtudomany.higienikus.hu/cikk/20153/2015-3.pdf Elérve: 2017. 09. 21. 